\title{
A new species of Rhetinantha (Orchidaceae, Maxillarieae) from Antioquia, Colombia
}

\author{
Dariusz L. Szlachetko • Marta Kolanowska
}

Received: 28 February 2013/Accepted: 11 May 2013/Published online: 26 May 2013

(C) The Author(s) 2013. This article is published with open access at Springerlink.com

\begin{abstract}
A new species of Rhetinantha from Colombian department of Antioquia is described, illustrated and placed within the key for the determination of national Rhetinantha species. The taxonomic affinity of the new entity is briefly discussed and the information about its distribution and ecology is provided.
\end{abstract}

Keywords Hoehnella - Orchids · New species . Rhetinantha $\cdot$ Sauvetrea

\section{Introduction}

As described by Ruiz and Pavón 1794, the genus Maxillaria is the largest and the most problematic within the subtribe Maxillariinae. The infrageneric variation of the vegetative as well as the floral characters forced numerous reclassification proposals. The necessity of the delimitation from Maxillaria smaller, clearly defined groups of species (=genera) were noticed way back-in the beginning of twentieth century five genera were accepted by Cogniaux (1904-1906) as valid taxa segregated from Maxillaria s.l. The broader concept and delimitation of the infrageneric sections only were supported by Dunsterville and Garay (1961), Pabst and Dungs (1977) as well as by Atwood and

D. L. Szlachetko · M. Kolanowska $(\bowtie)$

Department of Plant Taxonomy and Nature Conservation, University of Gdańskul, ul. Wita Stwosza 59, 80-308, Gdańsk, Poland

e-mail: martakolanowska@wp.pl
Mora de Retana (1999). The results of the molecular studies of Whitten et al. (2007) indicated the paraphyletic character of Maxillaria s.l. hereby suggesting the necessity of the further genera recognition within this taxon.

One of the species group clearly separated in the genetic research was Maxillaria acuminata clade embracing plants producing oblong, two-to four foliate, laterally flattened pseudobulbs, with inflorescence arising from bract axils between the second- and third-oldest pseudobulbs, the campanulate flowers with rigid, fibrous, acuminate to aristate tepals and the simple or obscurely three-lobed lip with a linear callus bearing a resinous/lipoidal secretion or waxy white crystals (Whitten et al. 2007). Three genera were segregated from this clade (Table 1): Rhetinantha M.A.Blanco, Sauvetrea Szlach. \& Sitko and the monotypic Hoehnella Szlach. and Sitko (Blanco et al. 2007; Szlachetko and Śmiszek 2007; Szlachetko et al. 2012). The first two taxa are distinguished by the the shape and situation of the lip callus. In this concept, Sauvetrea comprises 15 and Rhetinantha 20 species-all distributed from Mexico to Bolivia and Brazil.

According to the list compiled by Ortiz Valdivieso and Uribe Vélez (2007), eight species of Rhetinantha occur in Colombia: $R$. acuminata, $R$. friedrichsthallii, $R$. monacensis, $R$. notyliiglossa, $R$. ochroglossa, $R$. scorpioiodea, $R$. unguiculata and $R$. unguilabia. Their altitudinal range is wide and it extends from the near sea level up to over 2,000 m. a.s.l. (Ortiz Valdivieso and Uribe Vélez 2007).

The comprehensive studies on the Colombian Maxillariinae revealed the existence of undescribed Rhetinantha species in the department of Antioquia, where so far only one species of the genus, $R$. acuminata, was reported (Idárraga Piedrahíta et al. 2011). The characteristic and the line-drawing of the novelty are provided together with information about its ecology. 
Table 1 Comparative morphology of Hoehnella, Rhetinantha and Sauvetrea

\begin{tabular}{|c|c|c|c|}
\hline Character & Hoehnella & Rhetinantha & Sauvetrea \\
\hline $\begin{array}{l}\text { Pseudobulbs/ } \\
\text { stems }\end{array}$ & $\begin{array}{l}\text { Plants monopodial. Stem concealed } \\
\text { in the basal part by persistent, } \\
\text { distichous, imbricating sheaths, } \\
\text { leafy above }\end{array}$ & $\begin{array}{l}\text { Plants subcaespitose to long rhizomatous. } \\
\text { Pseudobulbs often ridged, covered } \\
\text { usually by one or two subtending } \\
\text { foliaceous sheaths }\end{array}$ & $\begin{array}{l}\text { Pseudobulbs ellipsoid to ovoid, slightly } \\
\text { flattened, frequently ancipitous, } \\
\text { subtendend by a pair of non-foliaceous, } \\
\text { acute, papery short-lived sheaths }\end{array}$ \\
\hline Leaves & $\begin{array}{l}\text { Leaves imbricating basally, laterally } \\
\text { compressed, acute, subfalcate, } \\
\text { thick, fleshy, soft }\end{array}$ & $\begin{array}{l}\text { Leaves } 1-4 \text {, at the apex of pseudobulb, } \\
\text { linear, unequally bilobed at the apex, } \\
\text { both lobes rounded }\end{array}$ & $\begin{array}{l}\text { Leaf single, oblong to elliptic-oblong, } \\
\text { membraneous to coriaceous, stiff }\end{array}$ \\
\hline Inflorescences & $\begin{array}{l}\text { Inflorescences axillary, } 1 \text {-flowered, } \\
\text { concealed by the leaves, peduncle } \\
\text { bearing } 2-4 \text { sheaths }\end{array}$ & $\begin{array}{l}\text { Inflorescences as long as or shorter than } \\
\text { leaves, often arising from rhizome bracts } \\
\text { a few shoots behind the most recent } \\
\text { pseudobulb }\end{array}$ & $\begin{array}{l}\text { Inflorescences from the base of the newly } \\
\text { emerging pseudobulbs, much longer than } \\
\text { pseudobulbs, usually as long as leaf, the } \\
\text { scapes with strongly ancipitous, two- } \\
\text { ranked, strongly keeled bracts }\end{array}$ \\
\hline Flowers & $\begin{array}{l}\text { Flowers tubular, borne singly in } \\
\text { leave axils, tepals stiff, thick, with } \\
\text { fibrous bundles }\end{array}$ & $\begin{array}{l}\text { Flowers campanulate, with rigid, } \\
\text { acuminate perianth parts with strong } \\
\text { fibers }\end{array}$ & $\begin{array}{l}\text { Flowers medium-sized, covered by } \\
\text { imbricating sheaths, with spreading } \\
\text { perianth segments, without strong fibers }\end{array}$ \\
\hline Tepals & $\begin{array}{l}\text { Sepals and petals dissimilar in size } \\
\text { and form }\end{array}$ & Sepals and petals subsimilar or dissimilar & Sepals and petals subsimilar, narrow \\
\hline Lip & $\begin{array}{l}\text { Lip shortly clawed, oblong-sagittate } \\
\text { in outline, very obscurely three- } \\
\text { lobed. Callus oblong, thick in the } \\
\text { lower half of the lip }\end{array}$ & $\begin{array}{l}\text { Lip clawed, oblong-obovate, ligulate- } \\
\text { lanceolate, pandurate to obscurely three- } \\
\text { lobed in the lower portion, secreting a } \\
\text { sticky, resinous substance in most } \\
\text { species. Callus prominent in the basal } \\
\text { third or so }\end{array}$ & $\begin{array}{l}\text { Lip sessile, hanging on the column foot, } \\
\text { unequally three-lobed. Callus central, } \\
\text { ligulate, with sulcate depression along its } \\
\text { length }\end{array}$ \\
\hline Gynostemium & $\begin{array}{l}\text { Gynostemium suberect, slender. } \\
\text { Margins of the clinandrium entire. } \\
\text { Column foot rudimentary }\end{array}$ & $\begin{array}{l}\text { Gynostemium slender, arcuate. Margins of } \\
\text { the clinandrium conspicuously ciliate. } \\
\text { Column foot short }\end{array}$ & $\begin{array}{l}\text { Gynostemium suberect, slender. Margins } \\
\text { of the clinandrium entire. Column foot } \\
\text { short }\end{array}$ \\
\hline $\begin{array}{l}\text { Fruit and } \\
\text { ovary }\end{array}$ & Terete & Terete & Strongly trigonous \\
\hline
\end{tabular}

\section{Materials and methods}

Dried herbarium specimens were examined according to the standard procedures. Each studied sheet was photographed and the data from the labels were taken. Both vegetative and generative characters of every plant were studied. The presence, shape, and size of the pseudobulb and leaf arrangement were examined first. Then, the construction of the inflorescence and the shape and size of the floral bracts were studied. The morphology of flower, including gynostemium, was examined after its softened in the boiling water. At the end of the measurements, the surface of each floral element was studied under a stereomicroscope.

Acronyms for herbaria cited in this paper followed Index Herbariorum (Thiers, continuously updated). The CorelDraw v.12 software was used for the preparation of the distribution map.

\section{Taxonomic treatment}

Rhetinantha betancuri Szlach. \& Kolan., sp. nov. (Figs. 1, 2)

Species similar to Rhetinantha monacensis (Kraenzl.) M. A. Blanco, from which it differs by the oblong pseudobulbs, lip truncate at the base, prominently expanded above it and broadly obovate, centrally concave lip callus.

Type: Betancur \& al. 14699-Colombia, Antioquia, Mpio. Urrao. Corregimiento La Encarnación. Vereda Calles, Parque Nacional Natural Las Orquideas, en frente de la cabana de Calles, $6^{\circ} 32^{\prime} 20^{\prime \prime} \mathrm{N} 76^{\circ} 14^{\prime} 51^{\prime \prime} \mathrm{W}$, alt. 1,350-1,360 m (29 Jan 2011), (COL! holotype).

In rhizomatous, creeping plants, pseudobulbs up to $1.5 \mathrm{~cm}$ long and $0.5 \mathrm{~cm}$ wide, oblong, laterally compressed, bifoliate. Leaves up to $5.5 \mathrm{~cm}$ long and $0.5 \mathrm{~cm}$ wide, linear, bilobulate apically, lobules rounded. Peduncle $3-4 \mathrm{~cm}$ long, 

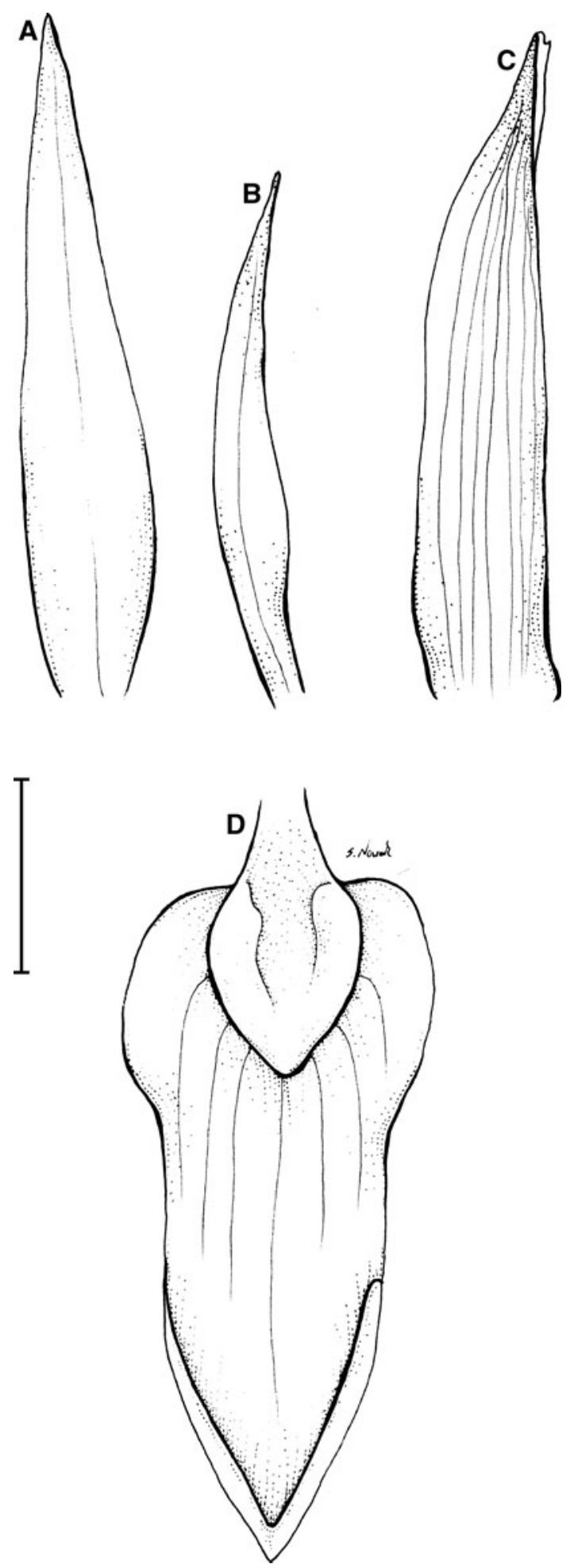

Fig. 1 Rhetinantha betancuri-dissected perianth: a dorsal sepal, b petal; c lateral sepal; d lip. Scale bar $5 \mathrm{~mm}$. Drawn by S. Nowak from the holotype enclothed with 7-8, imbricating sheaths. Flowers rather small. Floral bracts at $10 \mathrm{~mm}$ long, oblong-lanceolate, acute. Pedicellate ovary to $12 \mathrm{~mm}$ long. Tepals and lip with fibrous vascular bundles. Dorsal sepal $17 \mathrm{~mm}$ long, $3.5 \mathrm{~mm}$ wide, narrowly linear, acuminate. Petals $13 \mathrm{~mm}$ long, $1.5 \mathrm{~mm}$ wide, linear, subulate above the middle, acuminate, falcate. Lateral sepals $16 \mathrm{~mm}$ long, $3 \mathrm{~mm}$ wide, oblonglanceolate, acute, keeled outside, subfalcate. Lip shortly but prominently clawed; lamina $9.5 \mathrm{~mm}$ long, $4 \mathrm{~mm}$ wide, ligulate-lanceolate in outline, base truncate, distinctly expanded above base forming ear-like lateral lobes, apically triangular, prominently thickened along margins, acute; callus broadly obovate, subobtuse towards apex, distinctly concave in the centre. Gynostemium $6 \mathrm{~mm}$ long.

Etymology: dedicated to Julio Betancur, co-collector of the type specimen.

Distribution and ecology: so far known only from the Western Cordillera in the Colombian department of Antioquia (Fig. 3). The new species grows epiphytically in premontane rainforest. Alt. 1,350-1,360 m. Flowering in January.

Representative material: Betancur \& al. 14699-Colombia, Antioquia. Mpio. Urrao, Corregimiento La Encarnación. Vereda Calles, Parque Nacional Natural Las Orquideas, en frente de la cabana de Calles, $6^{\circ} 32^{\prime} 20^{\prime \prime} \mathrm{N}$ $76^{\circ} 14^{\prime} 51^{\prime \prime} \mathrm{W}$, alt. 1,350-1,360 m (29 Jan 2011), (COL!); Betancur \& al. 14606-Colombia, Antioquia, Corregimiento La Encarnación, Vereda Calles, Parque Nacional Natural Las Orquideas, en frente de la cabana de Calles, $6^{\circ} 31^{\prime} 9.1^{\prime \prime} \mathrm{N} 76^{\circ} 15^{\prime} 8.4^{\prime \prime} \mathrm{W}$, Vegetacion secundaria a la orilla del rio Calles, alt. 1,357 m (25 Jan 2011), (COL!); Betancur \& al. 14673-Colombia, Antioquia, Corregimiento La Encarnación. Vereda Calles, Parque Nacional Natural Las Orquideas, en frente de la cabana de Calles, $6^{\circ} 32^{\prime} 20^{\prime \prime} \mathrm{N}$ $76^{\circ} 14^{\prime} 51^{\prime \prime} \mathrm{W}$, alt. 1,350-1,360 m (28 Jan 2011), (COL!).

Taxonomic notes: This species is closely allied to its Colombian congener, Rhetinantha monacensis (Kraenzl.) M. A. Blanco. The new entity is easily separable from the latter, by having narrower, oblong pseudobulbs, peduncle distinctly shorter than pseudobulbs and leaves, and first of all, lip form. It is truncate at the base, distinctly expanded just above it, and lip callus is massive, broadly obovate, concave in the centre.

Key to the Colombian species of Rhetinantha

1. Lip entire, linear-ligulate to subpandurate-oblong ........ 2

1* Lip 3-lobed, with rounded to triangular basal lobes and oblong middle lobe 7

2. Lip widened in the basal part ......... 3 
Fig. 2 Comparison of the floral characters of Rhetinantha betancuri (a) and R. monacensis (b). Drawn by S. Nowak
A
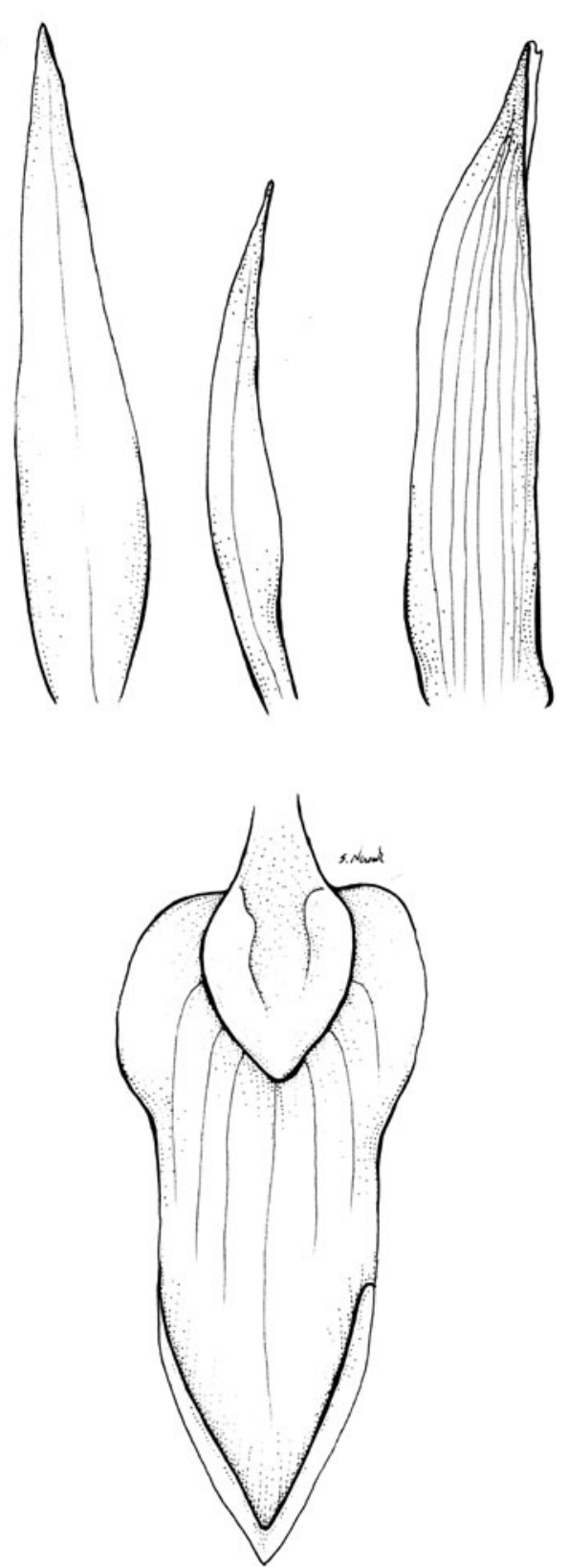
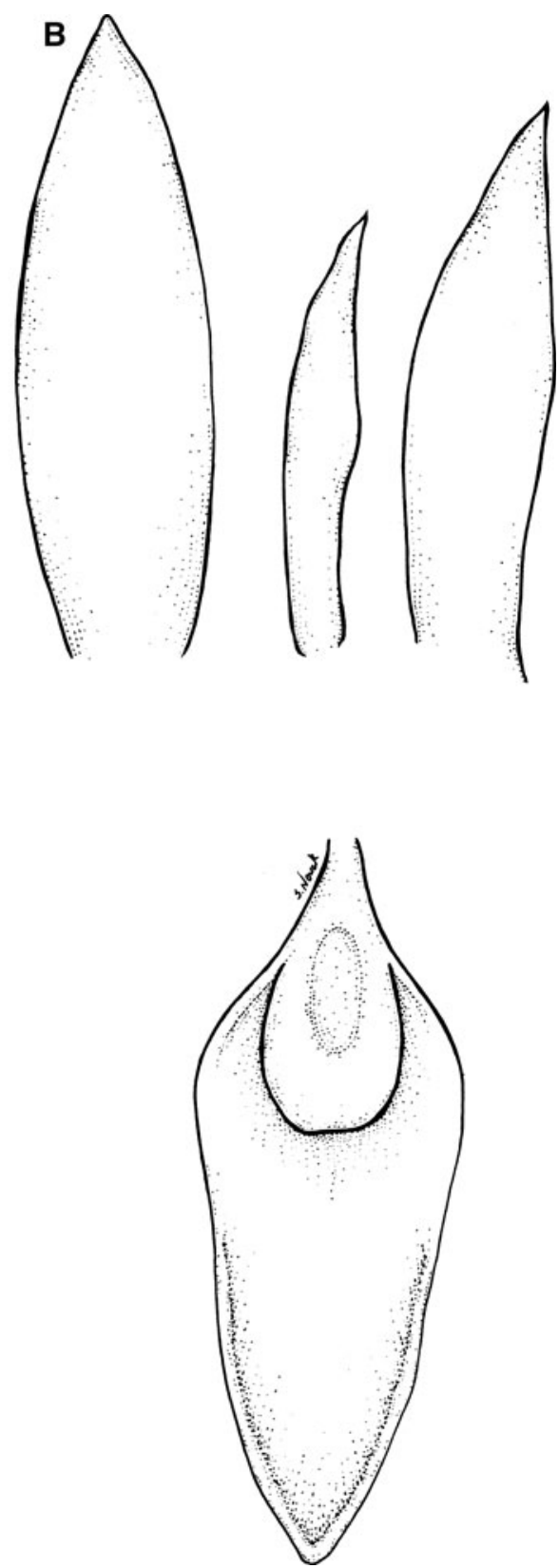

2* Lip linear-ligulate to narrowly-elliptic .... 5

3. Lip subpandurate-oblong in outline, obtuse at apex ....... R. acuminata

3* Lip ligulate-lanceolate to oblong-ovate, acute at apex ................ 4

4. Peduncle longer than pseudobulbs monacensis

4* Peduncle shorter than pseudobulbs betancuri

5. Peduncle short, about $2 \mathrm{~cm}$ long ochroglossa

5* Peduncle long, up to $4 \mathrm{~cm}$ long 6
6. The uppermost floral bract $11-17 \mathrm{~mm}$ long, column 9-11 mm long R. friedrichsthallii

6* The uppermost floral bract 16-21 mm long, column 12-14 mm long R. scorpioiodea

7. Middle lobe of the lip triangular ........R. notyliiglossa

7* Middle lobe of the lip oblong-ligulate to oblong ....... 8

R. 8. Petals subfalcate-linear, margin minutely papilloseciliate R. unguilabia

8* Petals obliquely lanceolate-ligulate, margins entire ...... R. unguiculata 


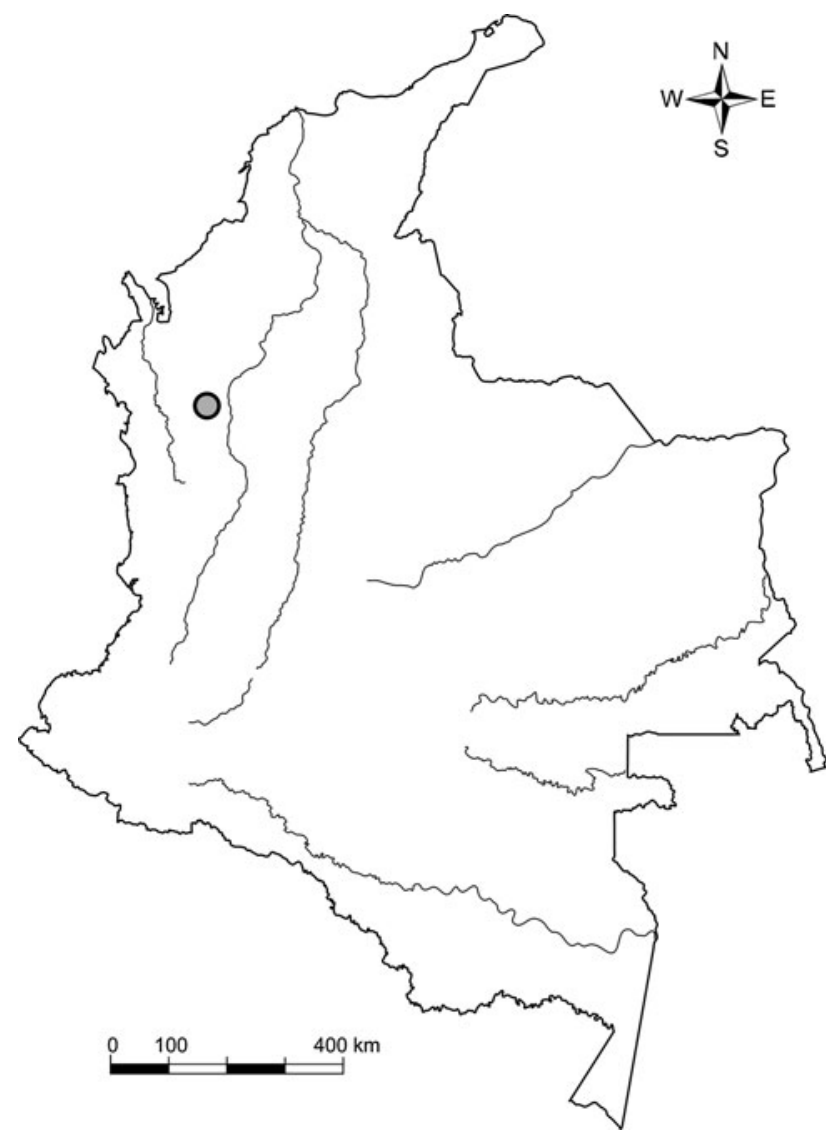

Fig. 3 Locality of Rhetinantha betancuri in Colombia

Acknowledgments The curators and staff of the cited herbaria are thanked for their kind hospitality and assistance during visits and for making specimens available on loan. We are grateful to Sławomir Nowak for preparing the illustrations. The research described here has been supported by the Polish Ministry of Science and Higher Education (research Grant no. 8124/B/PO1/2011/40).
Open Access This article is distributed under the terms of the Creative Commons Attribution License which permits any use, distribution, and reproduction in any medium, provided the original author(s) and the source are credited.

\section{References}

Atwood JT, Mora de Retana DE (1999) Flora Costaricensis (Orchidaceae). Fieldiana, Bot. 40:1-182

Blanco MA, Carnevali G, Whitten WM, Singer RB, Koehler S, Williams NH, Ojeda I, Neubig KM, Endara L (2007) Generic realignments in Maxillariinae (Orchidaceae). Lankesteriana 7: $515-537$

Cogniaux A (1904-1906) Orchidaceae. In: Martius CFP, Eichler AG, Urban I (eds) Fl Bras (Martius) v.3 pars 6. Fleischer, Leipzig

Dunsterville GCK, Garay LA (1961) Venezuelan orchids illustrated 2. Andre Deutsch, London

Ortiz Valdivieso P, Uribe Vélez C (2007) Galería de Orquídeas de Colombia (CD edition). Asociación Bogotana de Orquideología, Bogotá

Pabst GFJ, Dungs F (1977) Orchidaceae Brasilienses 2. Kurt Schmersow, Hildesheim

Idárraga Piedrahíta A, del Carmen Ortiz R, Callejas Posada R, Merello M (2011) Flora de Antioquia. Catálogo de las plantas vasculares. Volumen II. Listado de las Plantas Vasculares del departamento de Antioquia. D’Vinni, Bogotá

Ruiz H, Pavón J (1794) Maxillaria. Fl Peruv Prodr 1:219-226

Szlachetko DL, Śmiszek M (2007) Nouveaux genres dans le complex Maxillaria (Orchidaceae). Richardiana 7:26-32

Szlachetko DL, Sitko M, Tukałło P, Mytnik-Ejsmont J (2012) Taxonomy of the subtribe Maxillariinae (Orchidaceae, Vandoideae) revised. Biodiv Res Conserv 25:13-38

Thiers B (continuously updated) Index Herbariorum. A global directory of public herbaria and associated staff. New York Botanical Garden's Virtual Herbarium. http://sweetgum.nybg.org/ih/

Whitten WM, Williams NH, Blanco MA, Endara L, Neubig K, Koehler S, Carnevali G, Singer R (2007) Molecular phylogenetics of Maxillaria and related genera (Orchidaceae: Cymbidieae) based upon combined molecular data sets. Am J Bot 94:1860-1889 